\title{
WATER QUALITY CORRECTION WITHIN WATER DISTRIBUTION SYSTEM
}

\author{
KORYGOWANIE JAKOŚCI WODY W SYSTEMIE DYSTRYBUCJI WODY
}

\begin{abstract}
Water suppliers can be treated as production companies whose main product is water delivered to their customers. The article presents problems connected with management of such companies in the conditions of secondary contamination in water distribution systems. This phenomenon exists in water networks all over the world. Its' presence is particularly visible in countries of former communistic block. In the article particular attention was devoted to the issue of water quality correction in the analysed systems. In the case of water distribution systems, former quality correction methods consisted in special treatment of water pumped into the system, flushing and cleaning of water pipes. In both these cases identification of water quality deficiencies resulted in significant water loss. The situation reflects management processes applied in the manufacturing industry of the 1940s. The authors of this paper put forward the concept of three water quality correction methods which would not entail such considerable water loss. The methods in question are intended for different network types. The implementation of proposed solutions could set new standards in management of distribution systems of water providers.
\end{abstract}

Keywords: water distribution system, water quality, secondary contamination, water quality correction methods

\section{Introduction}

The quality of water transported by distribution network to the consumers should meet the requirements set by international $[1,2]$ and national organizations. These requirements are relatively easy to fulfill at the entrance to the network. Unfortunately, the quality of transferred water can deteriorate within it, which is called secondary contamination [3]. The phenomenon of secondary water contamination in water supply systems widely appears around the world [4-8]. Causes of this phenomenon have different reasons, and factors affecting water contamination can be divided into several groups connected with: water, its treatment and entering into the water supply system, hydraulic conditions, and pipe age in water distribution system, piping material, and network structure [9-14].

\footnotetext{
${ }^{1}$ Faculty of Environmental Engineering, Lublin University of Technology, ul. Nadbystrzycka 40B, 20-618 Lublin, Poland, phone +48 8153844 30, email: B.Kowalska@pollub.pl

${ }^{2}$ Institute of Environmental Engineering, Off-Campus Faculty of Social Sciences in Stalowa Wola, The John Paul II Catholic University of Lublin, ul. Ofiar Katynia 6A, 37-450 Stalowa Wola, Poland, phone +48156422533, fax +48 158424951

*Corresponding author: B.Kowalska@pollub.pl
} 
Secondary contamination of water distributed in water supply systems has become one of the main problems in countries that recently undergone political transformation. In these countries, water supply systems were created in the late nineteenth and early twentieth century. Most of them were significantly developed and modified in the 60's and 70's of the XX century, when the demand for water in the cities was growing due to population increase, industrial development and lack of economic barriers of water consumption. This situation has changed after transformation from the communist system to capitalism. Poland might be an example. Decrease of tap water consumption with the trend continuing to the present day (Fig. 1), observed since early 90's, caused that currently most water supply systems consist of oversized pipelines and storage facilities. Change in design standards, shown in Figure 1 did not significantly improved this problem. In addition, after 1990 there was a sharp increase in the length of pipes' of exploited systems - from about 93 thousands $\mathrm{km}$ in 1990 to about 273 thousand $\mathrm{km}$ in 2010. Both these factors resulted in elongation of the time of water transport from the point of intake to the receiver [15, 16], with all its negative results as the following: precipitation of sludge $[17,18]$, microbiological risks [19, 20] or intensification of pipes' material impact on the transferred water quality [21-24].

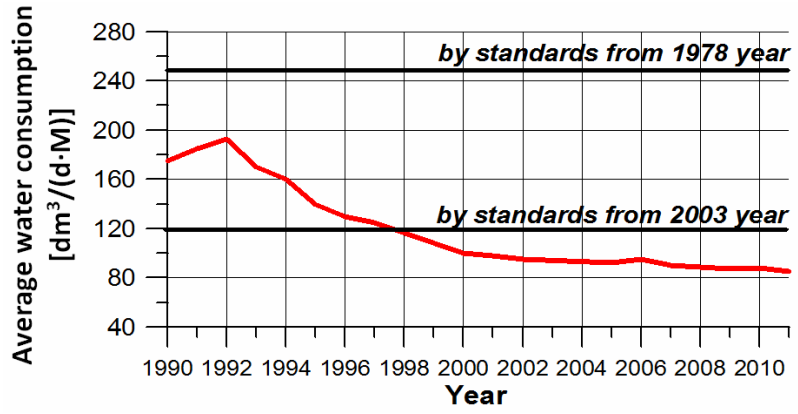

Fig. 1. Changes in the average per capita daily consumption of potable water in Poland in the last 20 years

Research conducted in Poland confirmed exceeding many factors of pollution in the water transported by water supply systems as a result of secondary contamination. In order to illustrate this phenomenon in the country, Figure 2 shows results of research conducted in 2006 in urban water supply system [22]. The studies of quality parameters were carried out on-line and with laboratory analyses in 132 Polish urban water supply systems. Analyzed systems provided water to 15 million people, which was $46.4 \%$ of people supplied by the collective water supply systems. In all cases, water pumped into the systems meets the quality requirements given by Polish standards and laws. Conducted research revealed that in every analyzed system exceed of permissible content of one or more of the assessed indicators of water pollution occurred. In $78 \%$ of the analyzed water supply systems the following parameters were most often exceeded: iron, manganese and turbidity, color, total number of bacteria cultured in $22^{\circ} \mathrm{C}$ and free chlorine. Rarely exceeded parameters are the following: ammonia, nitrates and nitrites, bacteria Coli, chloramines, fluorides, streptococci, $\mathrm{pH}$, water hardness and odour. 
It thus appears that, despite the maintenance of quality standards at the entrance to the distribution system, there is a possibility that the consumer will obtain water with deteriorated quality. It is necessary to search for methods to prevent the results and counteract the quality deterioration of transported water.

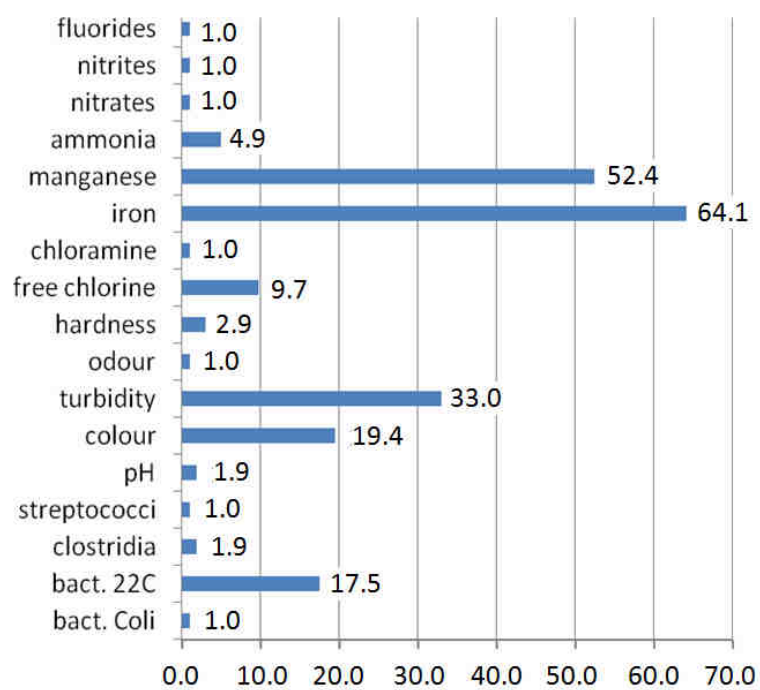

Fig. 2. Percentage share of systems, in which permissible content values of selected quality parameters of water taken from distribution system were exceeded - data from 2006 [22]

Purpose of this article is presentation of developed by the authors own methods to correct water quality in water supply system. In further part of the paper, three methods are presented - using network tanks, network treatment stations and mobile rinsing and water cleaning stations.

\section{Previous methods to prevent and counteract the phenomenon of secondary pollution}

Previous practice of water supply companies, related to preventing secondary contamination of water depended (and still depends) on a specialist water treatment (ensuring biological and chemical stability) introduced into the distribution network [23-26].

Counteracting the effects of secondary contamination is mainly based on more or less advanced methods of flushing and cleaning the distribution network [5, 15]. Among the latter, the first to be indicated is loss of large amount of water being in water supply system, and in many cases, the necessity of temporary shut-down parts of the network.

Taking into account the presented in the literature $[5,27,28]$ overview of the methods of flushing and cleaning of water supply systems, it should be noted that this issue is still developing. There are no universal methods which can be used with equal effectiveness in various conditions. There are also no methods that will significantly affect reduce of water losses and costs of the process of rinsing and cleaning. Accordingly, both operating service, 
and research and development centers are still looking for new, effective and more economical methods. The article presents three of such methods - using network tanks, network treatment stations and mobile water flushing and cleaning stations. These methods have been developed and patented in recent years by the team working in Department of Water Supply and Wastewater Sewage at the Faculty of Environmental Engineering, Lublin University of Technology [29-31].

\section{Concepts of methods for correcting water quality within the distribution network developed by the authors}

During the work on the own methods of water quality correction within the distribution network, the authors adopted the following assumptions:

- $\quad$ providing quality adjustment without loss of water contained in the part of water supply system,

- $\quad$ possibility to use in different types of networks (looped, branched, house connection pipes, end parts of network),

- possibility to flush piping without stopping water supply system,

- possibility to extend flushing time compared to traditional bleed flushing,

- $\quad$ enabling more frequent realization of flushing processes compared to traditional.

\section{Method using network tanks}

This method is intended for small looped and branched networks. The basis of this method is widely known fact of water flow increase in distribution network at the time of refilling network tanks lying away from supply point of this network. According to the authors, this phenomenon can be used to correct the quality of water accumulated in the pipes. For this purpose, existing water supply system should be modernized by equipping with an additional treatment plant and pumping station, located in direct vicinity of the tank, as shown in Figure 3.

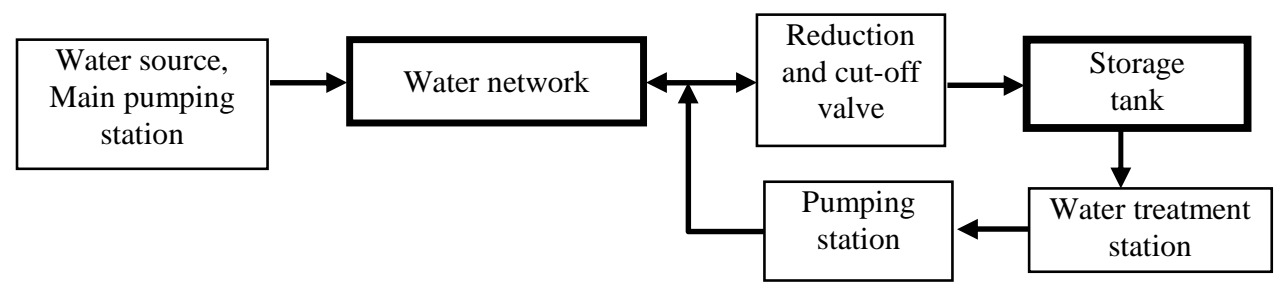

Fig. 3. Modernization of the water distribution system by the use of the network's storage tank as an element of correcting water quality in the network [27]

Proposed concept assumes that filling the tank will be carried out cyclically or intermittently, in the case of finding a degradation of water quality. Water accumulated in network pipes will be transported to the tank, and then, after re-treatment, may be directed to the distribution network. After filling the tank, distribution network will be supplied from it and previously used source. It is important that volume of the tank should be greater than or equal to the volume of water accumulated in network pipes supplying it. The task of reducing valve, shown in Figure 3, is regulation of the intensity of tank filling, and 
maintaining required pressure before the tank during its filling. Cut-off valve, shown in Figure 3, remains open only during filling. It should be noted that higher filling intensity, greater likelihood of achieving flushing rate in distribution pipes.

The assessment of applicability of this method was realized on the basis of simulation calculations carried out in the water supply system serving 4 thousand recipients. Calculations were performed using EPANET 2.0 [32]. Exemplary results of calculations are shown in Figure 4.
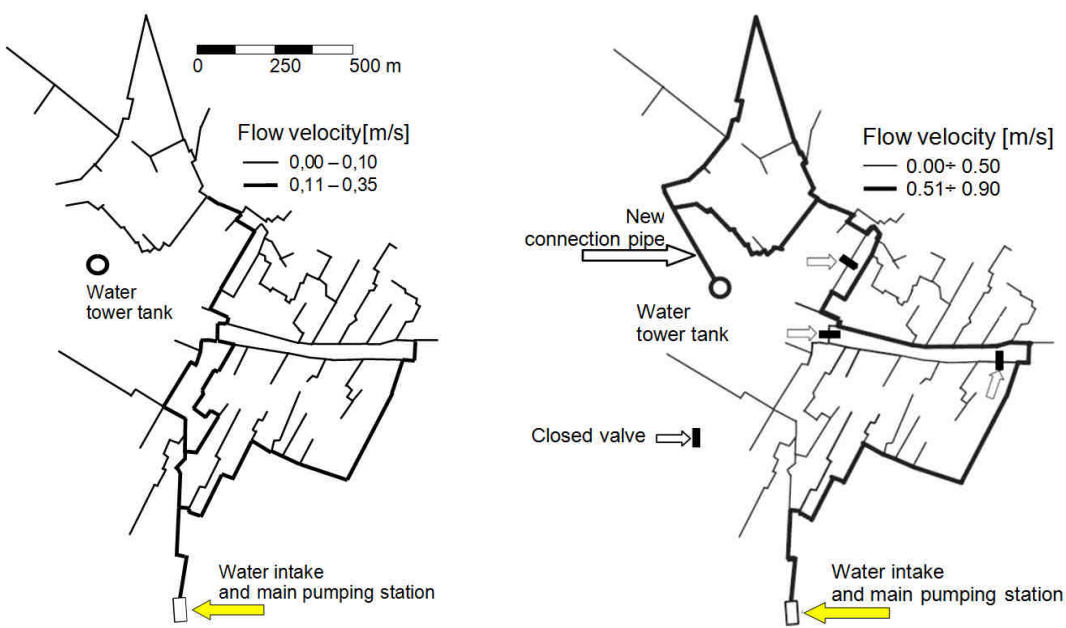

Fig. 4. Water velocity in the hour of maximum water demand in existing water network (left) and during water tank filling after their connection with network (right)

The above solution can somehow "recover", for distribution system, the water that is lost in traditional processes of correcting network water quality. Combination of the proposed system with enforcing targeted flow also allows for counteracting the effects of pipes' oversizing, periodically increasing flow rate in selected sections of the network. Implementation of remote control of network gates allows for covering various parts of the network with the proposed method of flushing.

\section{Method using network treatment plants}

This method was developed by the authors for looped network, in which end tanks does not appear. The idea of this method is based on the use of network treatment and flushing plants. The authors used here the possibility to force circulation of the water distributed within flushed network loops.

An exemplary technological scheme of such a station is shown in Figure 5. Plant proposed in Figure 5 should be built on the bypass of network pipe. After closing the end valve and opening bypass valve, all of the water will flow through the water treatment unit. Pumping station integrated with it should compensate pressure losses occurred during treatment. As a result, correcting of water quality flowing through the station is possible. Proposed concept, apart from the quality correction, also reduces water losses previously inseparable with this process. Use of suitable efficient circulating pumps and capacity of 
treatment plant adjusted to it, allows to obtain flushing velocity in pipes of the selected fragment of the network. Way of such a flushing can be changed by forcing directed flow.

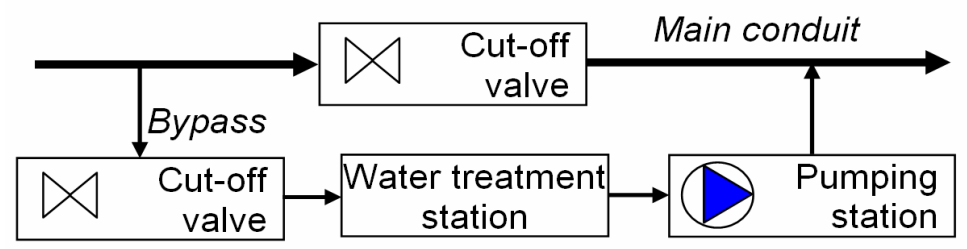

Fig. 5. Exemplary technological scheme of network treatment plant

The assessment of applicability the above method was carried out using a computer simulation in selected part of water supply system located in the city of about 50 thousand residents. Again, the simulation was performed using EPANET 2.0. For calculations, hydraulic resistance equal $15 \mathrm{~m} \mathrm{H}_{2} \mathrm{O}$ was assumed, and the station capacity is not limited. Results of exemplary calculations are shown in Figure 6.

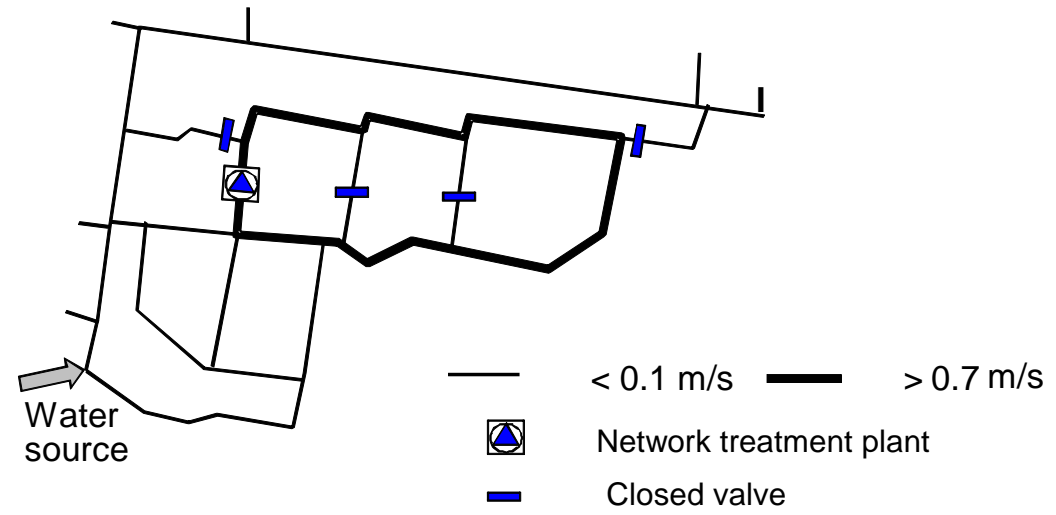

Fig. 6. Flow velocity in analyzed fragment of water supply system (2.00 a.m. after starting network treatment station and circulating pumps)

Flow distribution, shown in Figure 6, in the conditions of water treatment operating with exemplary configuration of closed network valves obtains that there is at least theoretical possibility to use proposed method to flush fragments of water supply system sections. At 2 a.m. the water consumption is minimal. Such flushing is done with significantly reduced water losses. There are some limitations of applying this method: sizes of filters in cleaning station, their hydraulic resistance and efficiency. An interesting solution in this case can be applying fluidized filters.

\section{Mobile flushing stations}

The effects of secondary water contamination are the most frequently observed in the end parts of water supply systems, as well as significantly oversized house connections. In 
both cases, water supply pipes' diameters do not exceed $150 \mathrm{~mm}$. In the previous practice, correcting the quality of water accumulated in them was mainly realized by discharge method, which was associated with significant water losses, and thus time limitation and frequency of flushing. Taking into account these problems, the authors developed method based on mobile flushing stations.

Operation of mobile flushing stations is based on the following [28]:

- closing flushing water circuit and connecting pipes' flushing with flushing water treatment,

- $\quad$ using hydrants as elements enabling access to flushed pipes,

- installing water spigots enabling connecting the station at the end of connection (before the water meter),

- $\quad$ using truck chassis to install a flushing station,

- realization of flushing process during the hour of minimal water demand.

Scheme of mobile flushing station is shown in Figure 7.

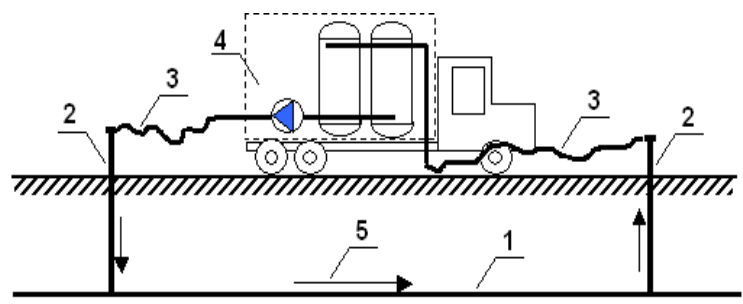

Fig. 7. Concept of Mobile Flushing Station: 1 - flushed pipe, 2 - fire hydrant, 3 - elastic pipe, 4 - flushing station, 5 - stream flow direction [28]

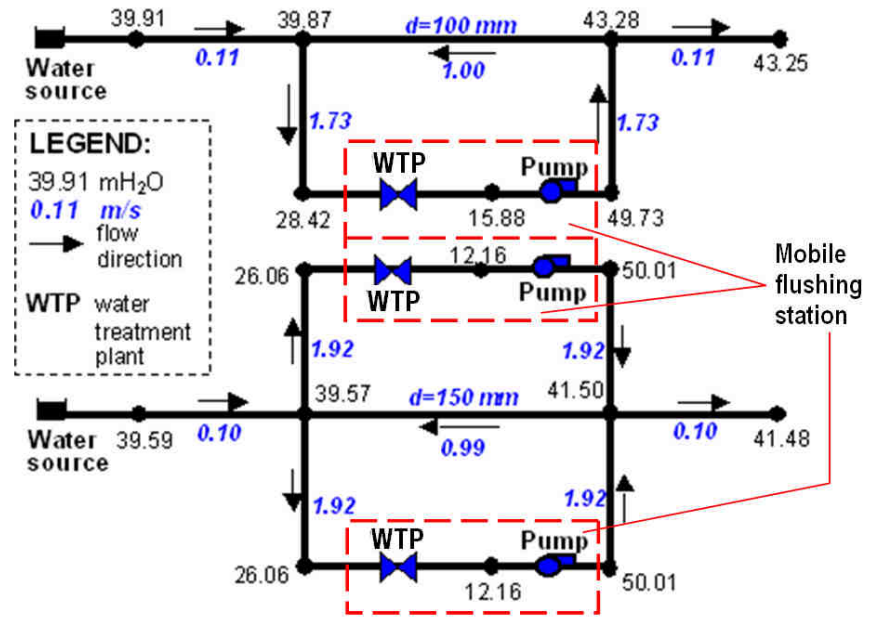

Fig. 8. Water flow velocity distribution and its pressure with using mobile flushing station, with flushing pipe with diameter of $100 \mathrm{~mm}$ (top) and $150 \mathrm{~mm}$ (bottom) 
Assessment of above method implementation possibility is based, as in previous cases, on numerical simulation studies carried out using EPANET 2.0. During the simulation two internal diameters of flushed pipes were considered:

- $100 \mathrm{~mm}$ - one flushing station was used,

- $150 \mathrm{~mm}$ - two parallel flushing sets were used,

- distance between connection hydrants is $100 \mathrm{~m}$.

Simulation results are shown in Figure 8.

In the presented method, flushing time and the number of water exchanges are limited by capacity of treatment system. In the case of network pipes (with diameters of $150 \mathrm{~mm}$ ), it was necessary to use two stations connected in parallel. Simulation research has shown that the effectiveness of proposed method can be limited by the necessity to provide a constant water supply to the consumers, even during flushing. In the cases when flushing is conducted at night or in the final parts of water supply system the risk is minimal. Unquestionable advantage in relation to traditional flushing method is saving water consumption. Disadvantage of this method is exploitation cost of the station, which is about 10-times greater than the cost of traditional flushing of water supply pipes.

\section{Conclusions}

Discussions and analyzes conducted in the article allows to draw the following conclusions:

- Problem of secondary contamination of water in distribution networks is present in many countries in the world, especially in post-communist countries, like Poland where fall in demand of water and rapid increase of the length of exploited network pipes are visible.

- To prevent secondary water contamination, the methods based on an appropriate water treatment at the input and flushing and cleaning network pipes are the most popular.

- Commonly used methods of flushing and cleaning network pipes were associated with the significant loss of water. Presented concepts of three methods of water quality correction in the network allow to reduce water losses.

- Simulation studies have shown that there are at least theoretical possibilities of the application of these methods in real distribution systems.

- One of the limitations of these methods application is necessity to use filters with high capacity, small sizes and high efficiency.

\section{Acknowledgements}

The work was presented at International Scientific and Technical Conference Water Treatment Technologies - Technical, Biological and Ecological Aspects, Kyiv 3-5 December 2013.

\section{References}

[1] Guidelines for Drinking - Water Quality. WHO, Geneva 2004.

[2] Drinking Water Directive 98/83/EC (1998). Council Directive of November 1998 on the quality of water intended for human consumption. Official J EC (L 330.5.12.98): 32-54.

[3] Mays L. Urban Water Supply Handbook. New York, Chicago, London, Madrid: Mc Graw Hill; 2002. 
[4] Besner MC, Gauthier V, Barbeau B, Millette R, Chapleau R, Prevost M. Journal AWWA. 2001;93(7):101-114.

[5] Vreeburg JHG, Boxall JB. Water Res. 2007;41(3):519-529. DOI: 10.1016/j.watres.2006.09.028.

[6] Elala D, Labhasetwar P, Tyrrel SF. Water Sci Technol. 2011;11(4):400-408. DOI: 10.2166/ws.2011.064.

[7] Mounce S, Machell J, Boxall J. Water Sci Technol. 2012;12(5): 580-587. DOI: 10.2166/ws.2012.030.

[8] Besner MC, Gauthier V, Trépanier M, Leclair M, Prévost M. Urban Water J. 2005;2(2):93-105. DOI: 10.1080/15730620500144340.

[9] Woolschlager JE, Rittmann BE, Piriou P. Urban Water J. 2005;2(2):69-79. DOI: $10.1080 / 15730620500144027$.

[10] Chen M, Ohman K, Sinclair J, Petkau D, Yau R, Deng JF, et al. Water Qual Res J Can. 2011;46(3):200-210. DOI: 10.2166/wqrjc.2011.021.

[11] Lee J, Lohani VK, Dietrich AM, Loganathan GV Water Sci Technol. 2012;12(5):619-629. DOI: 10.2166/ws.2012.036.

[12] Tsvetanova ZG, Hoekstra EJ. Water Sci Technol. 2012;12(4):489-495. DOI: 10.2166/ws.2012.022.

[13] Simard A, Pelletier G, Rodriguez MJ. Water Supply: Research and Technology - Aqua. 2011;60(6):375-390. DOI:10.2166/aqua.2011.019.

[14] Poças A, Rebola N, Cordeiro B, Rodrigues S, Benoliel M, Vreeburg J, Menaia J. Water Sci Technol. 2013;13(4):400-408. DOI:10.2166/ws.2013.096.

[15] Lehtola MJ, Nissinen TK, Miettinen IT. Water Res. 2004;38(3):601-610. DOI: 10.1016/j.watres.2003.10.054.

[16] Zimoch I, Łobos E. Desalin Water Treat. 2014;52(19-21):3719-3724. DOI: 10.1080/19443994.2014.884684.

[17] Tsvetanova ZG, Dimitrov DN. Water Sci Technol. 2012;12(6):720-726. DOI: 10.2166/ws.2012.048.

[18] Rahman MS, Gagnon GA. J Water Supply: Research and Technology - Aqua. 2014;63(6):461-475. DOI: 10.2166/aqua.2014.07.

[19] Ollos PJ, Huck PM, Slawson RM. Journal AWWA. 2003;95(1):87-97.

[20] Ellis K, Ryan B, Templeton MR, Biggs CA. Water Sci Technol. 2013;13(4):1034-1045. DOI: 10.2166/ws.2013.092.

[21] Kowalska B, Kowalski D, Rożej A: J Water Supply: Research and Technology - Aqua. 2011;60(3):137-146. DOI: 10.2166/aqua.2011.004.

[22] Chudzicki J, Kwietniewski M, Iwanek M, Suchorab P. In: Mambretti S, Brebbia CA. editors. Urban Water II, Suthampton, Boston: WIT Press; 2014; 15-17. http://www.witpress.com/books/978-1-84564-780-3.

[23] Fabris R, Braun K, Morran J, Ho L, Cook D, Drikas M. J Water Supply: Research and Technology - Aqua. 2013;62(6):377-384. DOI: 10.2166/aqua.2013.128.

[24] Vasyukova E, Proft R, Jousten J, Slavik I, Uhl W. Water Sci Technol. 2013;13(4):1099-1108. DOI: 10.2166/ws.2013.095.

[25] Lyon BA, Farré MJ, De Vera GA, Keller J, Roux A, Weinberg HS, et al. Water Sci Technol. 2014;14(4):681-689. DOI: 10.2166/ws.2014.0.

[26] Zhang M., Semmens M., Schuler D., Hozalski R. M. Journal AWWA. 2002;94(9):112-122.

[27] Kowalski D., Kowalska B., Kwietniewski M. Conference Cities of the future. Sustainable Urban Planning and Water Management. Stocholm 2011. http://www.cof2011 stockholm.se/?type=static\&id=45\&mo=33.

[28] Kowalski D. Water Practice Technol. 2009;4(3). DOI: 10.2166/wpt.2009.048.

[29] Polish patent no 378381. 2005. http://regserv.uprp.pl/register/application?lng=en\&number=P.378381.

[30] Polish patent no 378383. 2005. http://regserv.uprp.pl/register/application?number=P.378383.

[31] Polish patent no 378382. 2005. http://regserv.uprp.pl/register/application?number=P.378382.

[32] Rossman LA. Epanet 2. Users Manual. EPA/600/R-00/057. 2000. http://www2.epa.gov/water-research/ epanet\#downloads. 


\title{
KORYGOWANIE JAKOŚCI WODY W SYSTEMIE DYSTRYBUCJI WODY
}

\author{
${ }^{1}$ Wydział Inżynierii Środowiska, Politechnika Lubelska \\ ${ }^{2}$ Instytut Inżynierii Środowiska, Wydział Zamiejscowy Nauk o Społeczeństwie w Stalowej Woli \\ Katolicki Uniwersytet Lubelski Jana Pawła II
}

\begin{abstract}
Abstrakt: Przedsiębiorstwa wodociągowe mogą być traktowane jako zakłady produkcyjne, których głównym produktem jest woda dostarczana do odbiorców. W artykule autorzy zwracają uwagę na problematykę zarządzania takimi przedsiębiorstwami w warunkach występowania zjawiska wtórnego zanieczyszczenia wody w obrębie sieci wodociągowych. Problem wtórnego zanieczyszczenia dotyczy systemów wodociągowych na całym świecie, jednak szczególnie widoczny jest w krajach byłego bloku komunistycznego. W artykule zwrócono uwagę na problem korygowania jakości wody w obrębie sieci. W przypadku systemów dystrybucyjnych wody dotychczasowe metody korygowania opierały się głównie o specjalne uzdatnianie wtłaczanej do sieci wody oraz płukanie i czyszczenie przewodów sieciowych. W obu przypadkach stwierdzenie nieprawidłowej jakości wody w obrębie sieci dystrybucyjnej skutkowało znaczącymi stratami wody. Sytuacja ta odpowiada procesom zarządzania stosowanym w przemyśle produkcyjnym w latach 40. ubiegłego wieku. W artykule autorzy prezentują koncepcje opracowanych przez siebie czterech metod korygowania jakości przesyłanej wody, niewymagających jej znacznych strat. Metody te zostały dedykowane różnym typom sieci. Wdrożenie tych metod może zmienić standardy zarządzania systemami dystrybucyjnymi w przedsiębiorstwach wodociągowych.
\end{abstract}

Słowa kluczowe: system dystrybucji wody, jakość wody, wtórne zanieczyszczenie, metody korygowania jakości wody 